\title{
Characteristics and Productivity of the Sediments and Volcanic Rocks Aquifers in Sunuta Sub-Basin, Northeast Ethiopia
}

\author{
Gobeze Begashaw ${ }^{1}$ \\ Tafesse NT $^{2}$ id \\ 'Amhara Design and Supervision Works Enterprise \\ ${ }^{2}$ Department of Geology, University of Botswana, Botswana. \\ 2Email:tafesse24603@yahoo.com Tel: +267 75908000
}

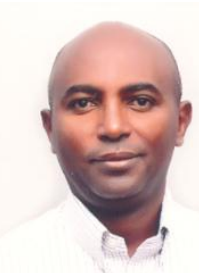

( Corresponding Author)

\begin{abstract}
Sunuta sub-basin is found within the lower Awash basin, Northeast Ethiopia, having an area of $1490.5 \mathrm{~km} 2$. The objective of the research was to characterize the different sediments and volcanic rocks aquifers and evaluate their respective productivity. To achieve these objectives, primary and secondary data were collected. Primary data such as geological, geological structures, and 82 water levels were collected during field investigation. 35 constant pumping test and 33 borehole $\log$ data were collected as secondary data from water offices in the area. With the exception of specific capacity, all other hydraulic properties were determined from recovery test data using Theis and Neuman analysis methods. Specific capacity was determined from constant discharge test data. The Mesozoic sandstone, Tertiary and Quaternary volcanic rocks and recent sediments are the main geological formations of the sub-basin. The aquifer types around the escarpments are unconfined whereas in the rift floor the aquifers are confined and semi-confined. In the rift floor the sediment thickness varies from 166-200m and also found interlayered with volcanic rock of rhyolite and basalt, forming multilayer confined and semi-confined aquifer. The general groundwater flow direction is from west to east. The different geological formations that are found constituting the area are categorized hydrogeologically into aquifer with intergranular weathered and fracture porosity and permeability, extensive aquifer with intergranular porosity and permeability and aquifer with fracture porosity and permeability. Analysis of pumping test data revealed that hydraulic conductivity ranges from 0.268 to $31.1 \mathrm{~m} /$ day and transmissivity ranges from 9.6 to $2420 \mathrm{~m}^{2}$ /day with mean values of $9.55 \mathrm{~m} /$ day and $632.79 \mathrm{~m}^{2} /$ day, respectively. Specific capacity ranges from 0.07 to $65.31 \mathrm{l} / \mathrm{sec} / \mathrm{m}$ with mean values of $5.45 \mathrm{l} / \mathrm{sec} / \mathrm{m}$. On the basis of their corresponding transmissivity and specific capacity value, the different aquifers of the studied area were categorized into three aquifer potentiality groups: low, moderate and high potentiality aquifer. Any future development of groundwater should be focused on the moderate and high potentiality aquifers.
\end{abstract}

Keywords: Afar depression, Aquifer types, Groundwater productivity, Hydraulic properties, Tertiary volcanics.

Citation | Gobeze Begashaw; Nata T. Tafesse (2017). Characteristics and Productivity of the Sediments and Volcanic Rocks Aquifers in Sunuta SubBasin, Northeast Ethiopia. Asian Review of Environmental and Earth Sciences, $4(1): 46-57$

History:

Received: 4 October 2017

Revised: 6 December 2017

Accepted: 11 December 2017

Published: 14 December 2017

Licensed: This work is licensed under a Creative Commons Attribution 3.0

License (c)

Publisher: Asian Online Journal Publishing Group
Contribution/Acknowledgement: Both authors contributed to the conception and design of the study.

Funding: The authors duly acknowledge Amhara Design and Supervision Works Enterprise for sponsoring this research work and providing the necessary data.

Competing Interests: The authors declare that they have no conflict of interests.
Transparency: The authors confirm that the manuscript is an honest, accurate, and Transparency: The authors confirm that the manuscript is an honest, accurate, and
transparent account of the study was reported; that no vital features of the study have transparent account of the study was reported; that no vital features of the study have
been omitted; and that any discrepancies from the study as planned have been explained. been omitted; and that any discrepancies from the study as plan
Ethical: This study follows all ethical practices during writing.

\section{Contents}

1. Introduction

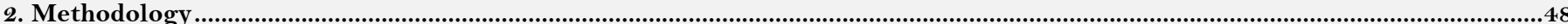

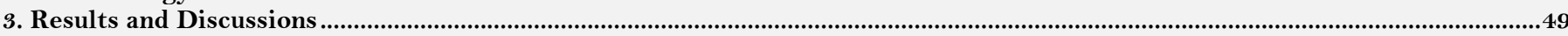

4. Conclusions

References 


\section{Introduction}

\subsection{Background}

Groundwater is the second largest available reservoir of fresh water [1]. Worldwide, more than 2 billion people depend on groundwater for their daily supply. A large proportion of the world's agriculture and irrigation is dependent on groundwater, as are a large number of industries. Whether groundwater or surface water is exploited for water supply is largely dependent on the location of aquifers relative to the point of demand [2]. In Ethiopia also groundwater is the major fresh water resource currently used as source for water supply, irrigation and industries.

The study area, Sunuta sub-basin, is well known by uneven distribution of rainfall, scarcity of rainfall, scarce surface water and frequent occurrence of drought. Most of the streams are intermittent. The communities' economy mainly depends on livestock production and in some parts in agriculture. Water problem is the main issue of the peoples living in this sub basin. This problem, even though, it has been there for long time at present it gets worst due to increased in the number residents, livestock's numbers and agricultural activities in the sub-basin.

Currently the Federal Democratic Republic of Ethiopian Ministry of Agriculture is undertaking an extensive plan for irrigation in the Awash basin (where the study area is located) of the Afar National Regional State in different zones using groundwater potential and surface waters to sustain food security of the region and for development of the country. Among the areas selected by the ministry for groundwater-based irrigation development is the study area.

The sustainability of this project is highly depending on the proper development, utilization and management of the groundwater of the area. Proper and sustainable development of groundwater on the other hand depends on proper well site locations that are normally done based on the knowledge of the characteristics of the different aquifers and their respective productivity. Such hydrogeological information's are not available in the Sunuta subbasin. This research that makes its objectives on characterization and productivity evaluation of the different aquifers is proposed to generate such kind of hydrogeological information's that can be employed for better development of groundwater in the sub-basin.

\subsection{Description of the Study Area}

\subsubsection{Location}

The study area is located in Afar National Regional State in Zone 4 of EwaWoreda and Amhara National Regional State in north Wollo zone. It is found at about $490 \mathrm{~km}$ northeast of Addis Ababa. Geographically, the sub-basin is located between the UTM coordinates of 556695 to $650305 \mathrm{~m} \mathrm{E}$ and 1292222 to $1335000 \mathrm{~m} \mathrm{~N}$, having an area of about $1497.5 \mathrm{sq} \mathrm{km}$ and a perimeter of $245.9 \mathrm{~km}$ (Figure 1). Hydrologically, the sub-basin is located within the Awash basin, an endorheic basin drain by a perennial river called Awash that flows along the rift valley into the Afar triangle.

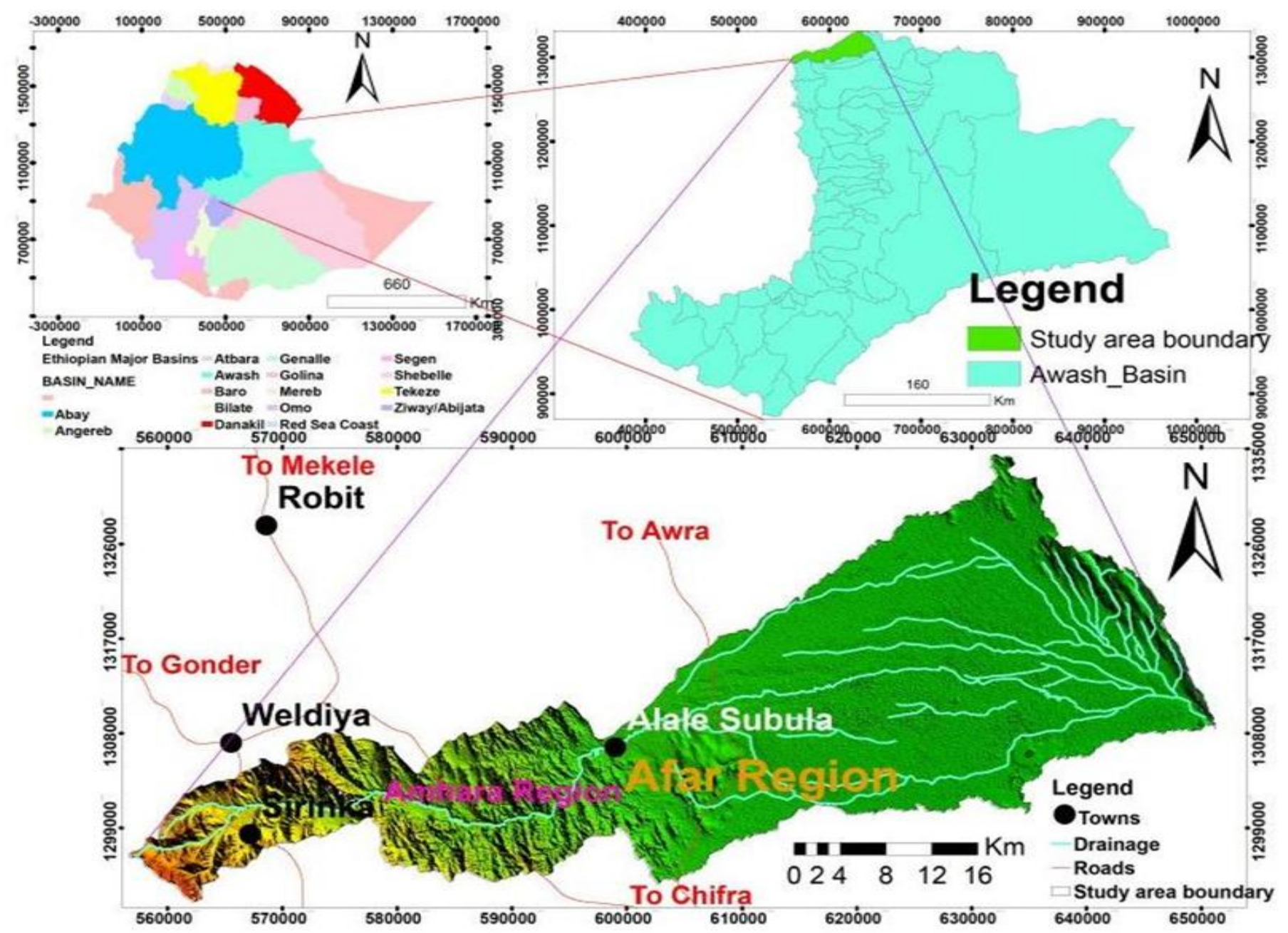

Source: Gobeze Begashaw, M.Sc. Thesis, University of Mekelle, Mekelle, Ethiopia, 2016.

\subsubsection{Phsiography and Drainage Pattern}

Topographically, the sub-basin is ranging from steep slope to flat land. The elevation ranges from $3479 \mathrm{~m}$ above sea level in the western side to $745 \mathrm{~m}$ above sea level in the northeastern parts. 
The dominate topography in the sub-basin is plain and very gently sloping $(0-4 \%)$ areas, which has an area coverage of $61 \%$ of the total study area. Gently sloping ( $4-8 \%$ ) areas coverage is $22 \%$ of the total study area. Areas that have a slope ranging from 8 to $30 \%$ and greater than $30 \%$ constituted $16 \%$ and $1 \%$ of the total study area, respectively. The elevation is decreasing from west to northeast sides of the sub-basin.

The climate of the area is semi-arid to arid with no or occasional rainy season. It is drained by few perennial rivers such as Chereti, Sirinka, and Uwa that rise from western and northwestern mountains (Figure 2). Among these only Uwa is the only river that crosses the study area with high discharge during wet season and low discharge during dry season. The discharge from this river percolates into the thick sediments of Sunuta plain in the eastern parts. Besides to these perennial rivers, the sub-basin is also drained by intermittent streams that rise from the western, northwestern, southwestern and southern mountains. With the exception of the northeastern parts of the area, the general flow direction of the rivers is west to east. In the northeastern parts of the sub-basin, the flow direction of the rivers is northwest to southeast. Generally the drainage pattern of the study area is dendritic (Figure 2).

\section{Methodology}

Different methods have been used to achieve the objectives of this research. Delineation of the study area was done from available topo maps using different software's, and then finalized by taking GPS readings at different sites of the study area for ground checking.

Collections of pertinent documents, previously done regional and nationwide geological and hydrogeological maps, different studied documents around the study area, geological logs and pumping test data of the existing boreholes in the study area from different organizations were done. Data for geology and hydrogeology were collected in the field with the help of GPS.

Geological and structural investigations as a technique was conducted in the field paying particular attention to the different features of the overlying sediments and underlying volcanic rocks units for groundwater storage and transmission. Landsat TM satellite image $15 \mathrm{~m}$ resolution was used to locate and delineate large-scale tectonic structures, specially, faults and fracture systems of the study area with conjunctive use of the field investigation. These discontinuity features are extracted and digitized using ARC GIS10.1 software.

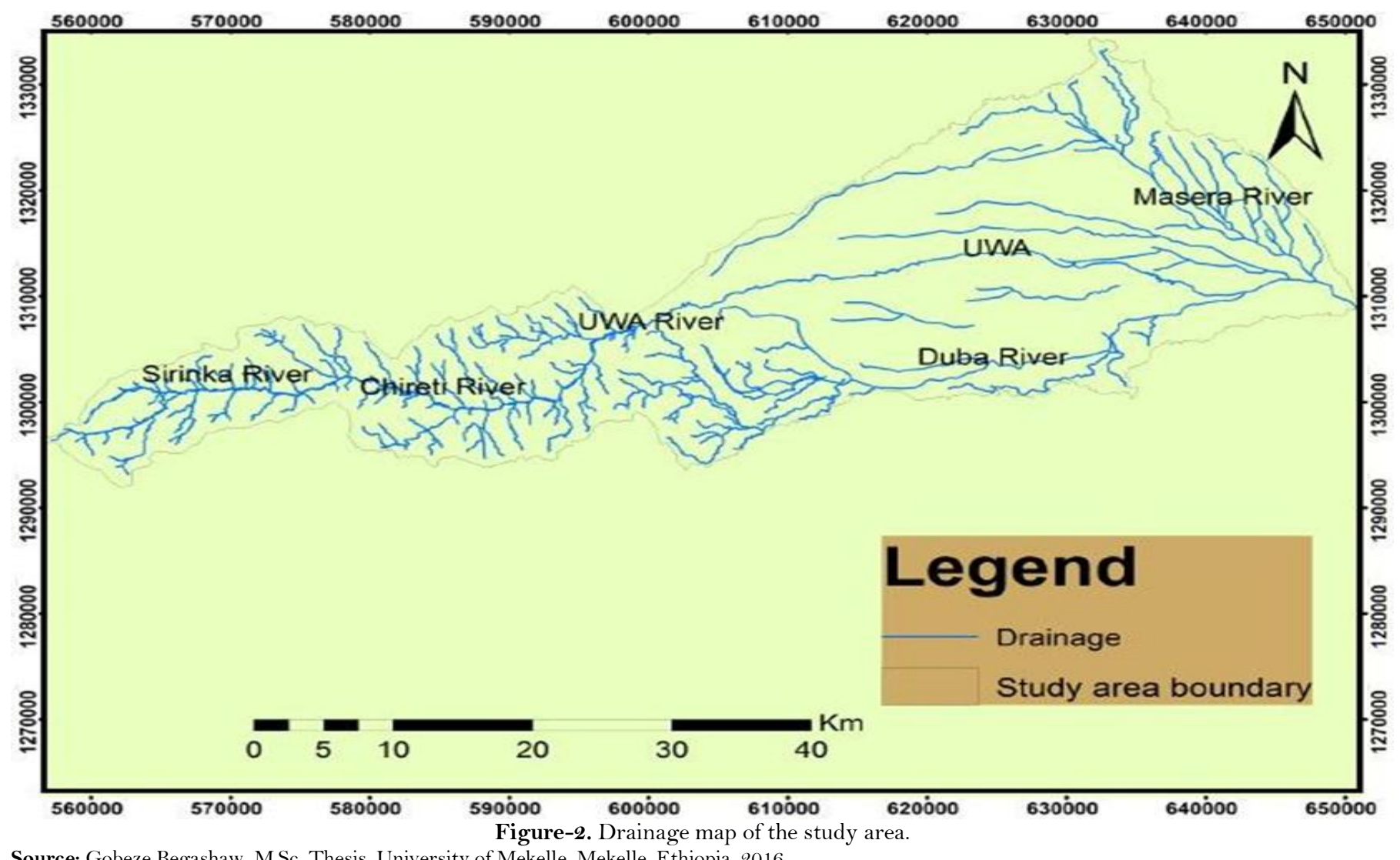

Source: Gobeze Begashaw, M.Sc. Thesis, University of Mekelle, Mekelle, Ethiopia, 2016.

Inventory of groundwater structures (boreholes and hand dug wells) were conducted as part of the hydrogeological investigation. Except the western area, most of the study area groundwater point elevation was obtained by Surveyor's level in order to have accurate well elevation. For determination of the hydraulic properties of the different aquifers 35 constant discharge and recovery pumping test data together with their corresponding geological and geophysical logs were used. The data were analyzed using AquiferTest v.3.5 software. With the exception of specific capacity, all other hydraulic properties were determined from recovery test data using Theis and Neuman analysis methods. Specific capacity was determined from constant discharge test data.

To determine the different aquifer types and also to characterize the nature of each aquifer besides to the preparation of hydrogeological logs, plots of pumping test data on semi-log scale (specialized plot) and Log-Log scale (diagnostic plot) were prepared for different deep wells using Microsoft office excel 2007 and the drawdown behavior were compared with the various theoretical models. Theoretical models comprise the type of aquifer and initial and boundary conditions [3]. According to this author, specialized plots are specific to a given flow system. Diagnostic plot allows the dominating flow regimes to be identified. 


\section{Results and Discussions}

\subsection{Geology}

\subsubsection{Regional Geology}

Ethiopia can be divided in to four major physiographic regions, known as the western plateau, southeastern plateau, the main rift and the Afar depression.

The Afar depression lies within the Afro-Arabian Rift System. This rift system extends from Syria in the north and passes through Jordan Valley, Dead Sea, Red Sea, Afar Depression, and East African Rift and terminates in southern Africa. The central part of the Afar depression is dominated by lowland plains corrugated by horsts and grabens and rare local high relief peaks representing shield volcanoes. It can be divided into northern, east-central, southeastern, and southwestern regions on the basis of similar structural trends [4]. Most of the Sunuta sub-basin is included in the southwestern part of the Afar depression in the south western region and partly it lies on the western escarpment (Figure 3). The geological units of the Afar depression and marginal areas can be divided into four broad groups: (1) Neoproterozoic basement, Mesozoic sedimentary rocks, and Eocene- Miocene basalts; (2) Miocene igneous rocks (3) Pliocene volcanic rocks (4) Quaternary volcanic and sedimentary rocks.

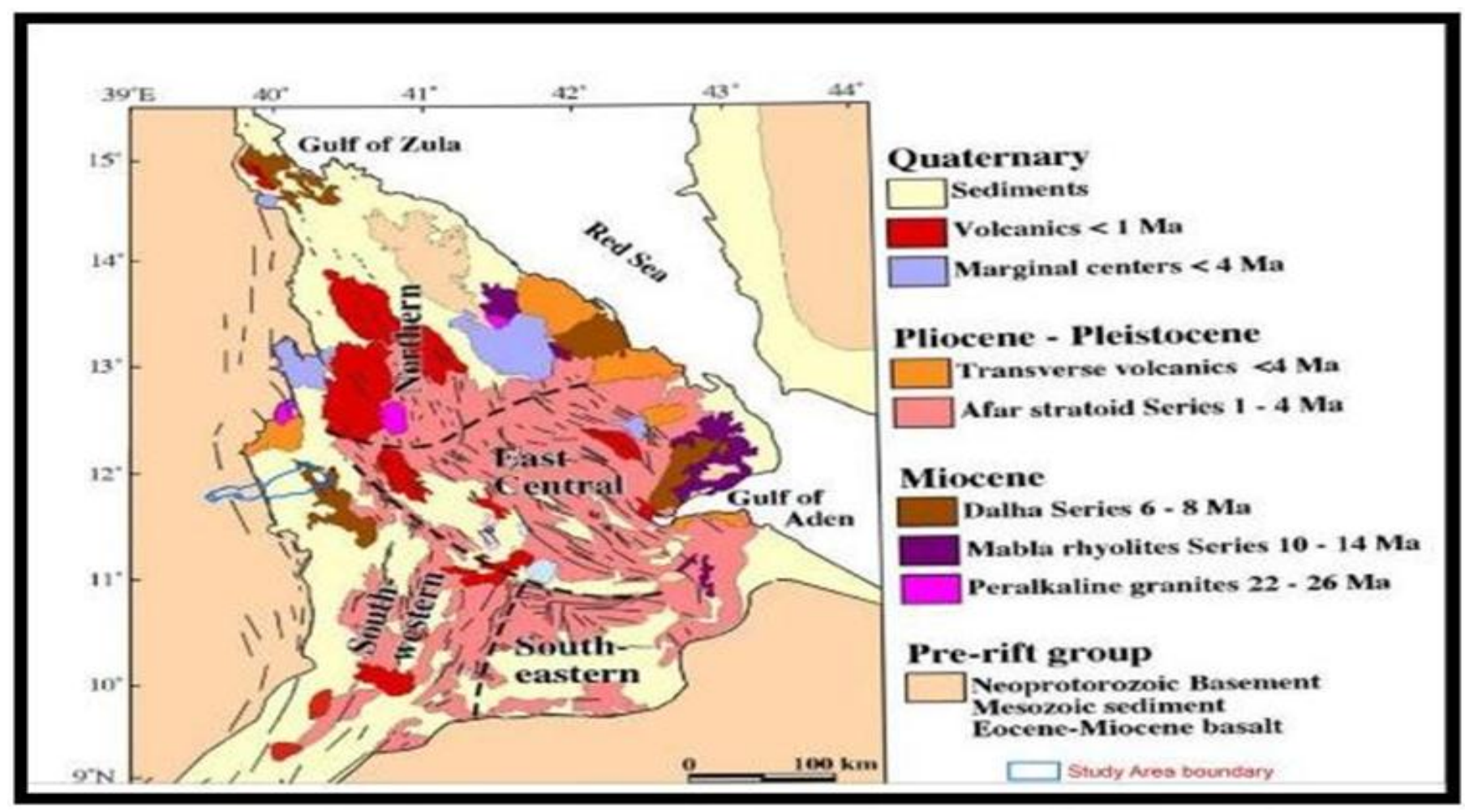

Figure-3. Geological map of the Afar depression (after $[5,6]$ ).

Source: Gobeze Begashaw, M.Sc. Thesis, University of Mekelle, Mekelle, Ethiopia, 2016.

\subsubsection{Local Geology}

\section{Sandstone}

The sandstone is exposed in the western area in a locality west of AleleSubula town $6 \mathrm{~km}$ at Messala ridge (595760 E, $1305598 \mathrm{~N}, 1246 \mathrm{~m})$ (Figure 5). The sandstone is existed underlying the Ashange basalts along NNWSSE trending normal faults and tilted along with the Ashange basalts by about 350 towards NNE. The upper part of the sandstone is red/pink in color, fine to coarse-grained and conglomeratic while the middle part is whitish and pebbly.

Petrographic studies by Water Works Design and Supervision Enterprise [7] reported that the sandstone is medium to coarse grained, equigranular with clastic texture, and is composed of quartz (90\%), opaque oxides (5\%) and alkali feldspar (3\%). Individual grains are angular to sub-rounded and well sorted. Quartz grains measure 0.5 $\mathrm{mm}$ on average but some are up to $2 \mathrm{~mm}$ long. Small amounts of rock fragments are also present. The cement is brownish ferruginous material.

\section{Basalts}

The western margin of the study area is covered by Ashange and Aiba basalt whereas the Dahala basalt covers the eastern margin of the study area (Figure 5).

The Ashange basalt is exposed in the Western escarpment at Hamaro, Humo, Sirinka, Dehawodih, and Merto area chains of ridges that extend north-south direction in the western parts of the study area. It is characterized by thinner individual lava flow thickness of about 5 meters and more alkaline affinity (Figure 4). This unit is highly weathered with alteration minerals filling in the vesicles forming amygdales. The individual flows of this unit are known to be continuous only for few kilometers along strike. 


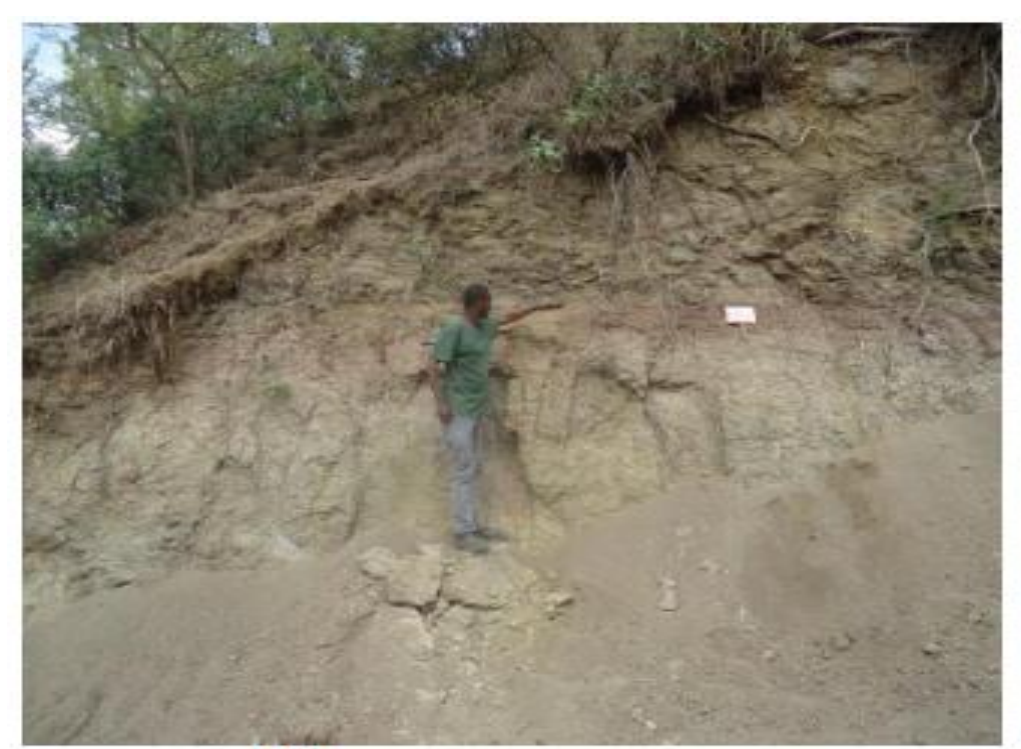

(a)

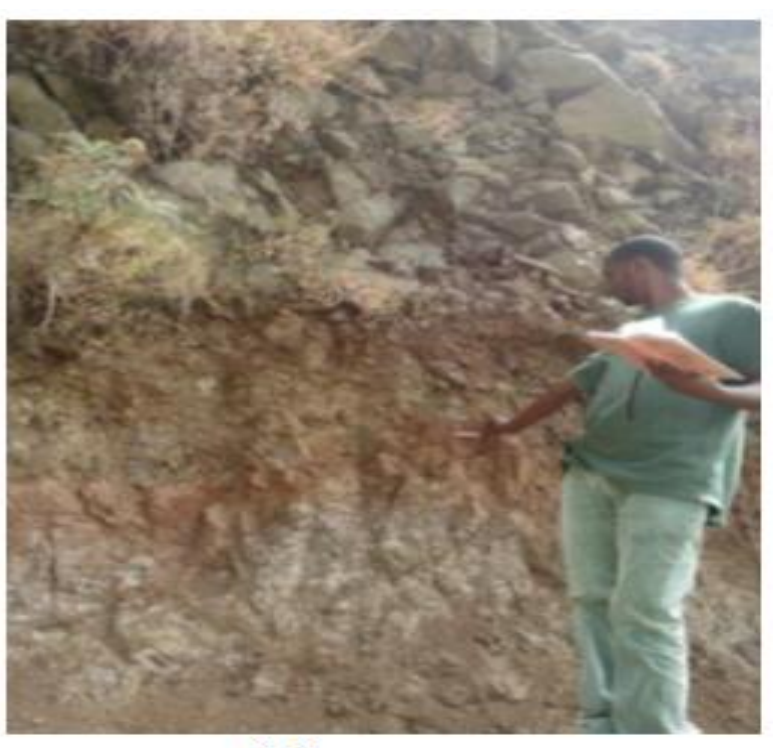

(b)

Figure-4.a) Contact between different flows of Ashange basalt: on the top part moderately weathered and fractured and the lower part is deeply weathered.

b) Contact between Aiba basalt without secondary material and the lower one is Ashange basalt with secondary material filling and the red color line with small thickness $0.3 \mathrm{~m}$ indicates paliosoil.

Source: Gobeze Begashaw, M.Sc. Thesis, University of Mekelle, Mekelle, Ethiopia, 2016.

\section{Granites}

This rock type is found in the form of dykes in the western parts of the study area (Figure 5). It is well exposed in Sirinka and Amaro area. The Sirinka granite, which has grey color, is the longest one extended from Sirinka to Alwuha away from the study area cutting the Ashange basalt with strike of 250NE. The granite has a grey and pink to red color, scarcely fractured in the top part whereas with depth it has a massive nature.

Petrographic studies by Water Works Design and Supervision Enterprise [7] reported that the granite is holocrystalline, coarse grained and inequigranular/moderately porphyritic (20\%) and partly glomeroporphyritic. Phenocrystminerals are dominated by quartz $(70 \%)$ and include alkali feldspar (sanidine) ( 30\%). Quartz is subhedral to anhedral and measures up to $5 \mathrm{~mm}$ long. Alkali feldspar, which is also euhedral to subhedral, has tabular habit and measures up to $1.5 \mathrm{~mm}$ long. The remaining smaller-sized minerals are constituted of equal proportions of quartz, sodic plagioclase, sanidine, myrmekite and small amounts of opaque oxides.

\section{Mabla Rhyolite}

The Mabalaryolite is found in the western and northeastern parts of the study area forming isolated hills and ridges (Figure 5). In the western parts the unit is highly affected by NNW-SSE trending faults and also tilted eastward.

Petrographic studies by Water Works Design and Supervision Enterprise (2011) reported that the rhyolite has vitrophyritic texture, and is composed of micrroclitic volcanic glass $(\sim 70 \%)$, rock fragment ( $\sim 22 \%)$, quartz $(\sim 6 \%)$ and fine-anhedral opaque Fe-oxide $(\sim 2 \%)$. The groundmass is composed of volcanic glass and rock fragments that consist of rhyolite and pumice.

\section{Fluvio-Lacustrine Sediments}

These are found covering the plain areas in the western (Sirinka plain and Woydo plain) and eastern (Sunuta plain) parts of the study area (Figure 5). Recent sediments are also found having limited areal extent along the river courses in the different parts of the study area.

Because of high elevation and slope variation between the eastern and western parts of the study area, erosion, transportation and denudation created on the western parts favors for the eastern parts of the study area to become depositional area. The sediments don't have uniformity in terms of grain size and thickness throughout the area where they are found. They area consist of clay, silt, sand and gravel. In the eastern parts (Sunuta plain) the thickness of the sediments varies from $166-200 \mathrm{~m}$ whereas in the western parts it varies from $18-50 \mathrm{~m}$. The sediments are also found interlayering with basalt.

\subsubsection{Geological Structures}

Generally in the study area, there are two related structural features; the Afar depression and the western escarpment that formed by down-warping and subsequent faulting and rift ward tilting of fault blocks. The major structures are fractures, joints, lineaments and faults. The length of fractures, lineaments and faults varies from 2-6 $\mathrm{km}$ with different trends. Their major trends of these structures are N-S, E-W, NW-SE and NE-SW. The dominant trend in the western parts (around Sirinka) of the study area is NNW-SSE direction. 

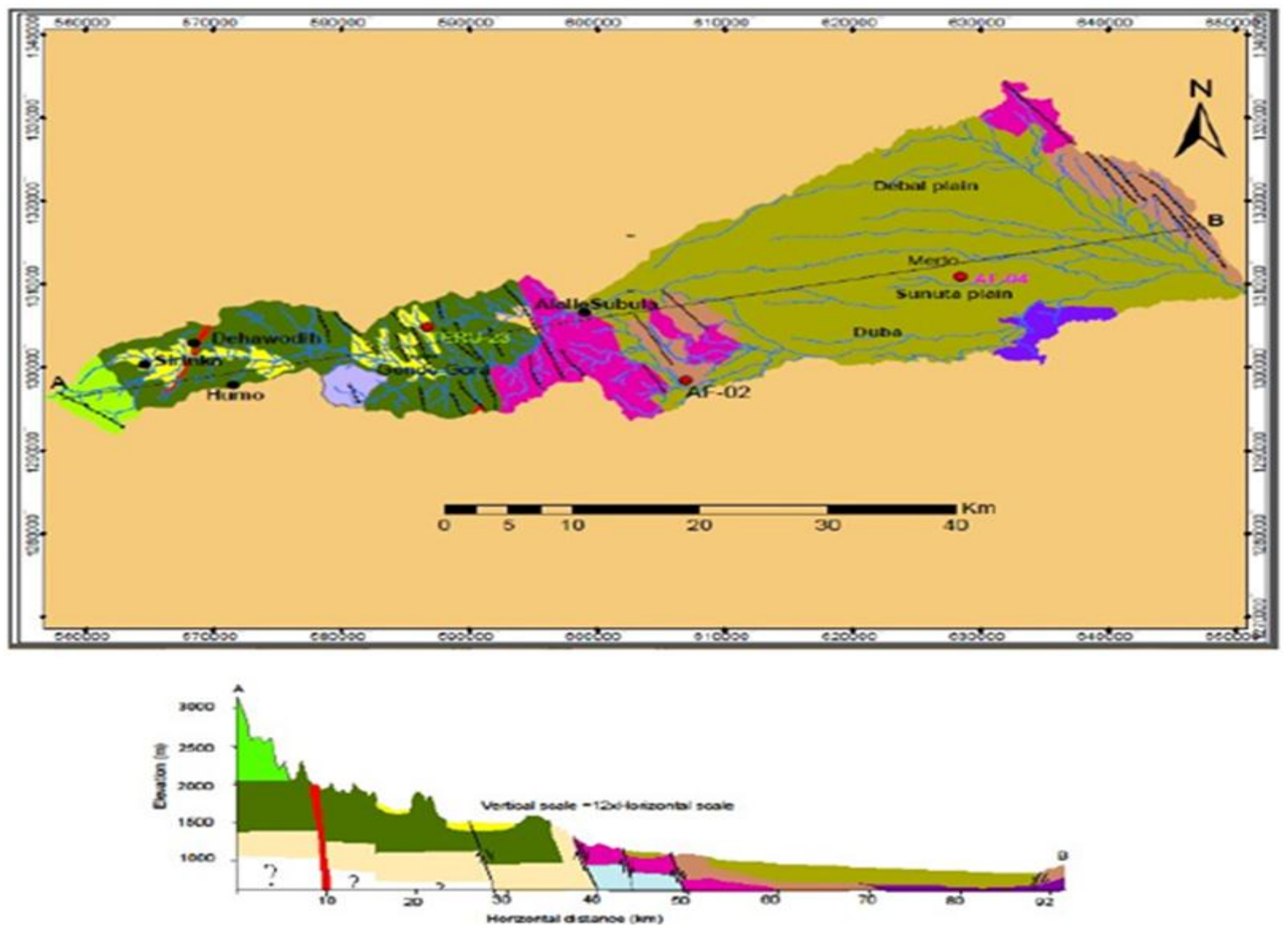

\section{Legend}

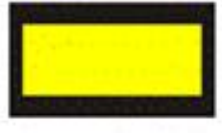

Alluvium

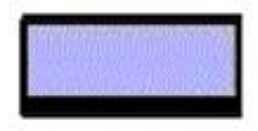

Fursa Rhyolite

Inferred fault

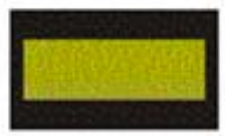

Fluvial-lacustrine sediments

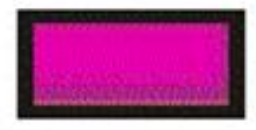

Mabla Rhyolite

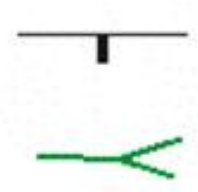

Fault

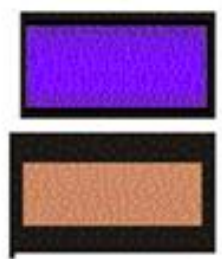

Recent basalt and scoria cones

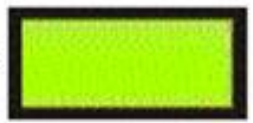

Aiba basalt

Dalha basalt

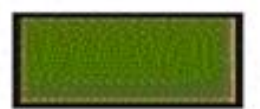

Ashange basalt

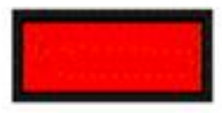

Granite intrusion

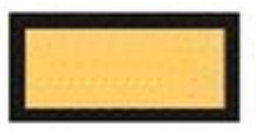

Upper sandstone

Figure-5. Geological map of the study area and cross-section from A to B.

Source: Gobeze Begashaw, M.Sc. Thesis, University of Mekelle, Mekelle, Ethiopia, 2016.

\subsection{Hydrogeology}

\subsubsection{General}

The saturated aquifer thickness of the sub-basin depended on the existence or not of the interlayered and underlying weathered and fractured volcanic rocks and the nature of the sediments. The interlayered and/or underlying volcanic rocks have variable weathered and fractured zones thickness, which is also serving as an aquifer.

In the sub-basin the water level ranges from $2.65 \mathrm{~m}$ to $79.54 \mathrm{~m}$ with a mean of $54.89 \mathrm{~m}$. The deeper water level is found in the eastern parts (Sunuta plain) whereas in the western parts the water level is not deep. In the study area most of the drilled boreholes show that water table greater than $40 \mathrm{~m}$ depth.

\subsubsection{Aquifer Types}

Interpreting a pumping test is primarily a matter of identifying an unknown system. System identification relies on models, the characteristics of which are assumed to represent the characteristics of the real aquifer system. Theoretical models comprise the type of aquifer (Figure 6), and initial and boundary conditions. In a pumping test, the type of aquifer and the inner and outer boundary conditions dominate at different times during the test. They affect the drawdown behavior of the system in their own individual ways. Therefore,to identify an aquifer system, one must compare its drawdown behavior with that of the various theoretical models. The model that compares best with the real system is then selected for the calculation of the hydraulic characteristics. System identification includes the construction of diagnostic plots and specialized plots. Diagnostic plots are log-log plots of the 
drawdown versus the time since pumping started. Specialized plots are semi-log plots of drawdown versus time, or drawdown versus distance to the well; they are specific to a given flow regime. A diagnostic plot allows the dominating flow regimes to be identified; these yield straight lines on specialized plots. The characteristic shapes of the curves can help in selecting the appropriate model. The choice of theoretical model is a crucial step in the interpretation of pumping tests. If the wrong model is chosen, the hydraulic characteristics calculated for the real aquifer will not be correct [3]. Depending up on this theoretical log-log and semi-log plots models, the actual pumping test executed have been plotted using Microsoft excel in log-log and semi-log form to compare with the theoretical and also with conjunctive use of the actual field data of the geological and hydrogeological log data. The aquifer is categorized based on these theoretical curves as confined, unconfined and semi-confined aquifer (Figures 7 - 9). Because of different reasons the pumping test data does not exactly fit with theoretical curves, careful analysis were made to distinguish the layers from the hydrogeological log data. The alluvial aquifer has thick clay, silt, sand and gravel on the top part and the underlain material is fractured basaltic rocks and beneath this rock unit is massive basalts.
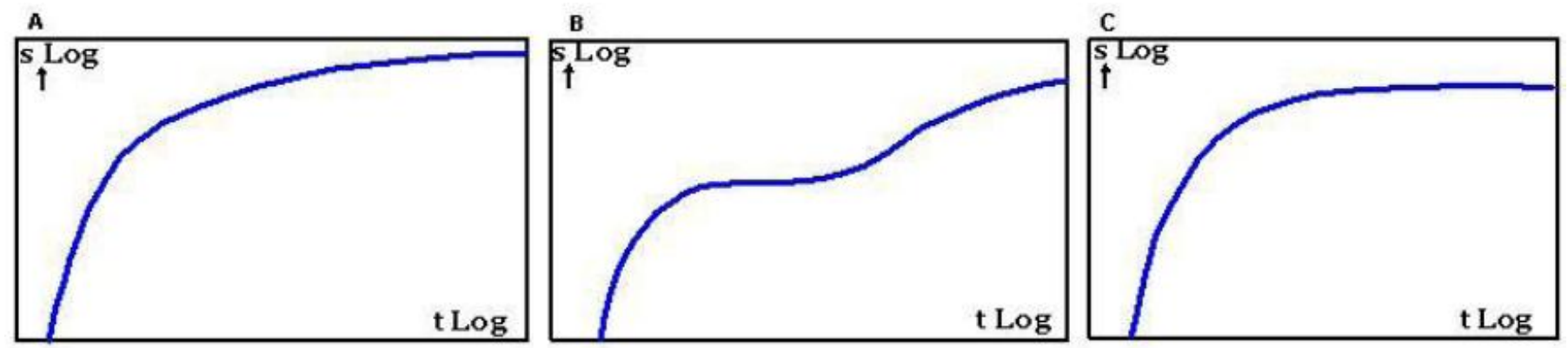

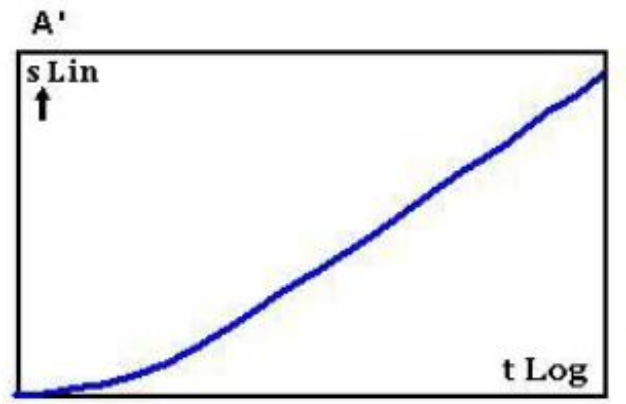

Confined aquifer

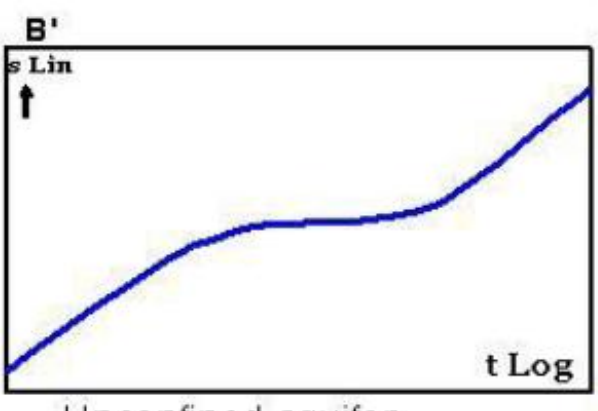

Unconfined aquifer

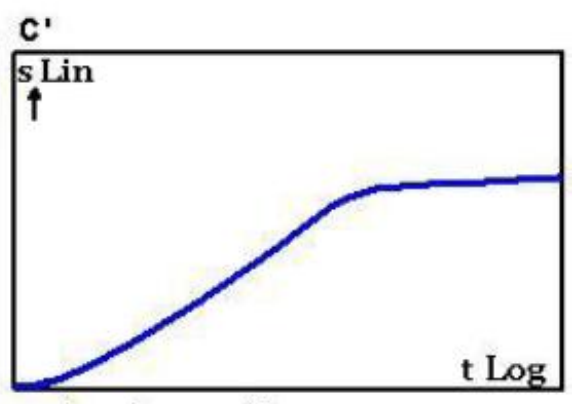

Leaky aquifer

Figure-6. Log-log and Semi-Log plots of the theoretical drawdown.

Source: Gobeze Begashaw, M.Sc. Thesis, University of Mekelle, Mekelle, Ethiopia, 2016.

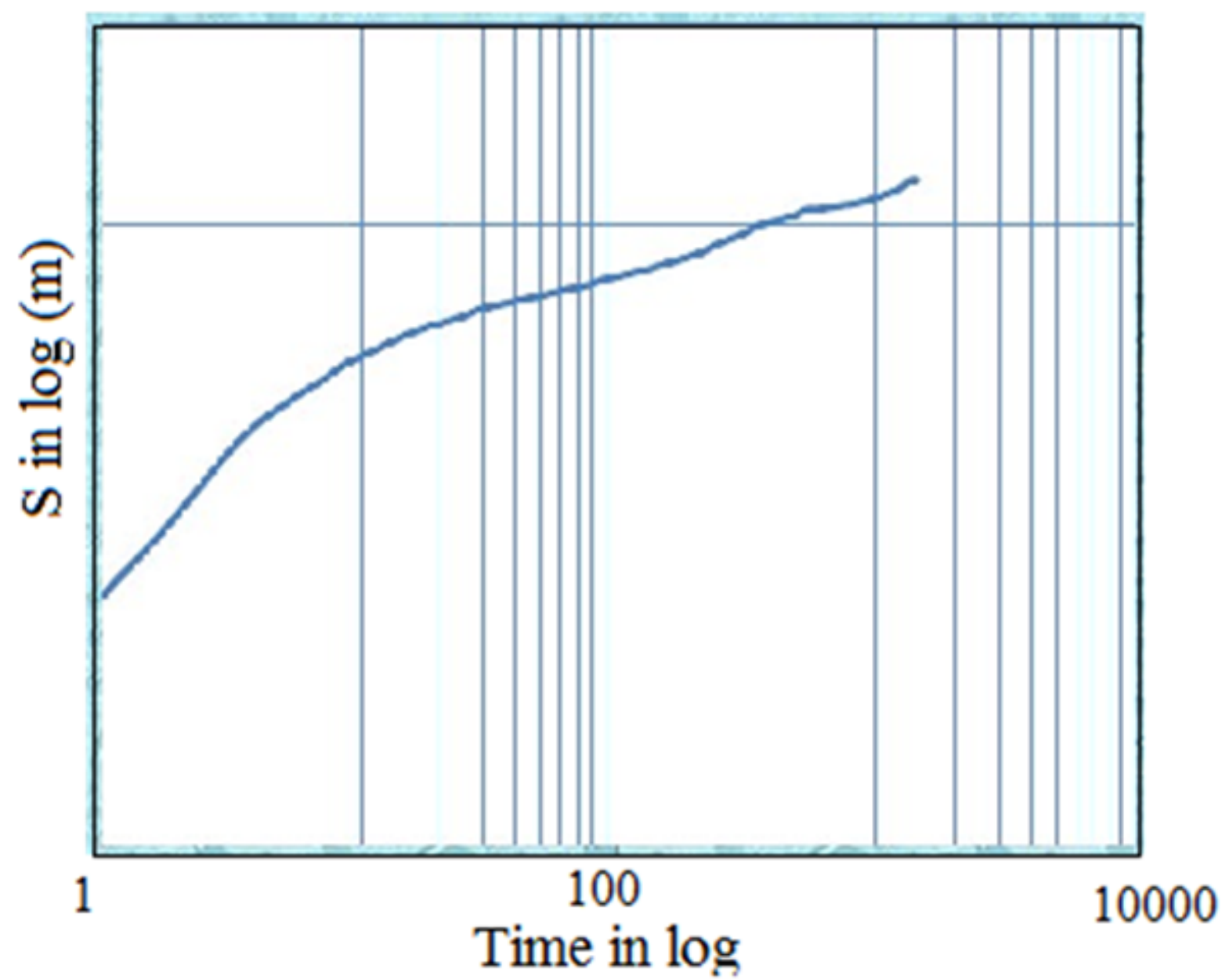

Figure-7. $\log -\log$ plots of Badule water supply well showing unconfined aquifer.

Source: Gobeze Begashaw, M.Sc. Thesis, University of Mekelle, Mekelle, Ethiopia, 2016. 


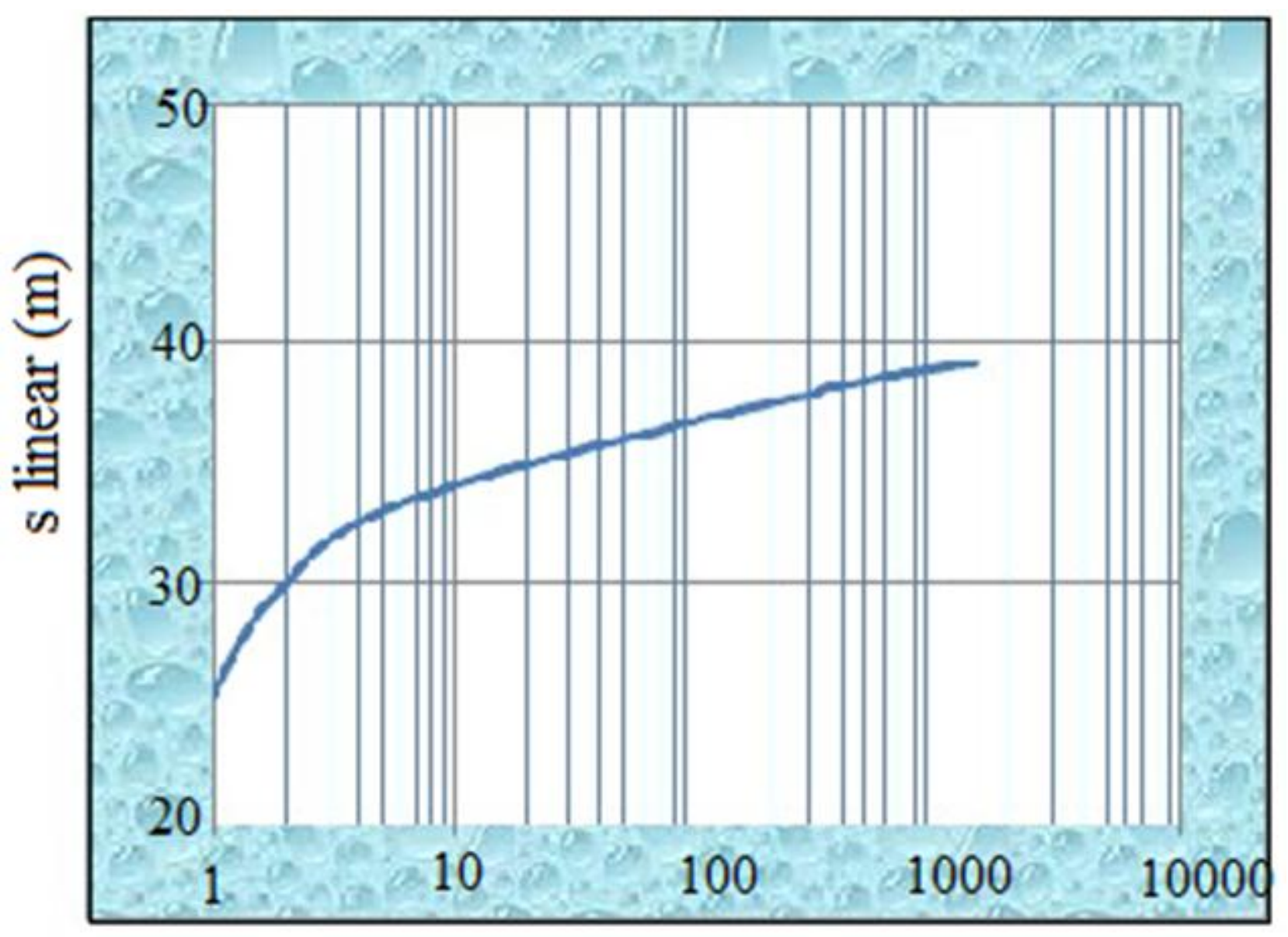

\section{Time in log}

Figure-8. Semi-log plots of SW 17 water supply well showing Semi-confined aquifer nature. Source: Gobeze Begashaw, M.Sc. Thesis, University of Mekelle, Mekelle, Ethiopia, 2016.

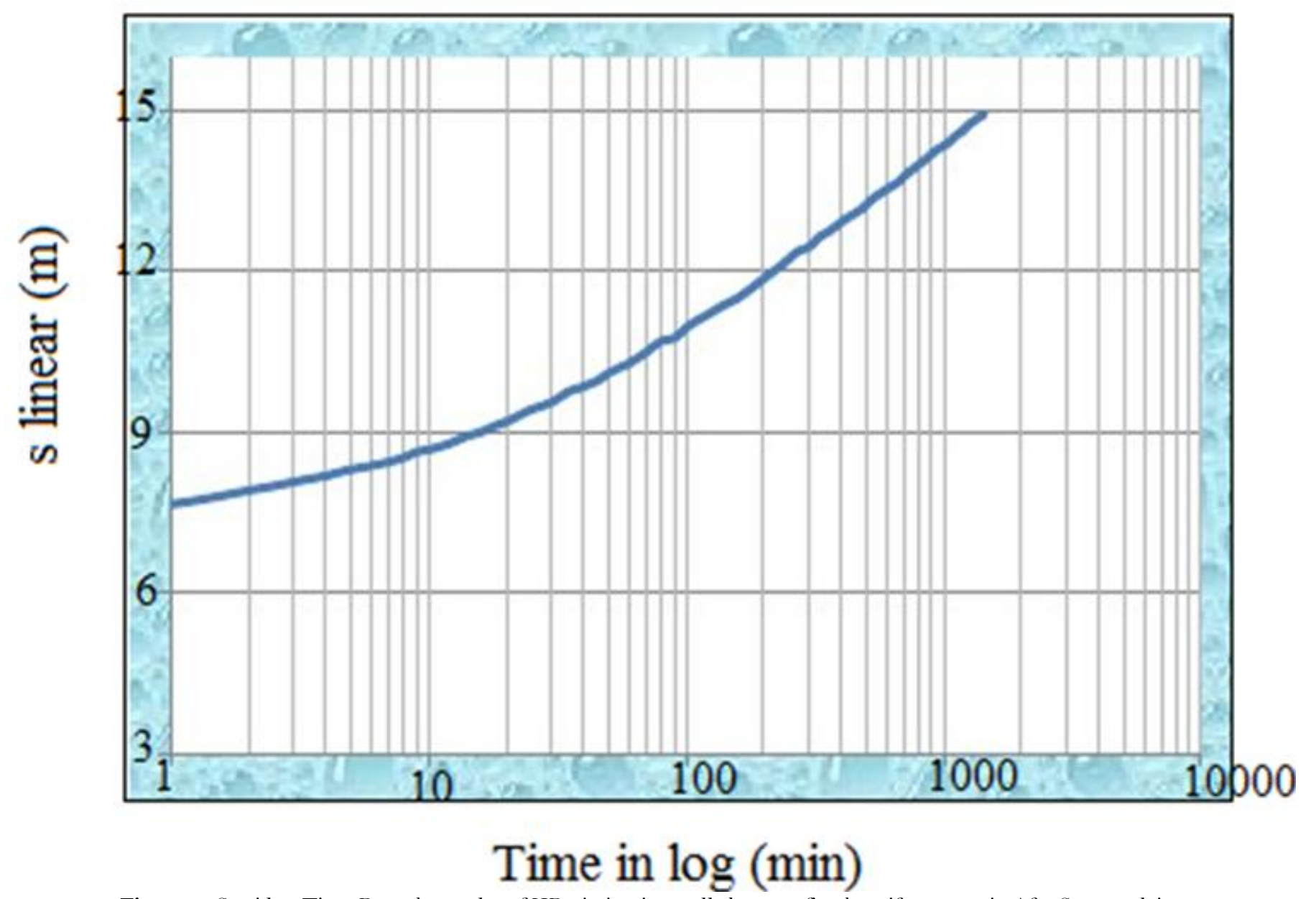

Figure-9. Semi log Time-Drawdown plot of HDQ irrigation well show confined aquifer nature in Afar Sunuta plain. Source: Gobeze Begashaw, M.Sc. Thesis, University of Mekelle, Mekelle, Ethiopia, 2016.

\subsubsection{Aquifer Characterization}

The study area is characterized by highly rugged topography in the western area, which is dominantly covered by volcanic rocks, and the low land, which is plain area covered by unconsolidated sediments and volcanic rocks. Unconsolidated sediments underlying by the volcanic rocks of different types are found covering 60 percent of the total study area whereas volcanic rocks of different types are found exposed on the surface on the remaining 40 percent of the total area. This lithological variation favors the study area to have multi later aquifer system which 
is sediment-volcanic- sediment-volcanic types of aquifer system mainly observed in the low land area in the eastern parts. The western parts of the study area also have alluvial sediments in Sirinka, and Woydo area underlying by basaltic rock, which is the major water bearing formation in this part of the sub-basin. Based on such occurrences, hydrogeologically these geological formations are categorized into three medium: aquifer with intergranular weathered and fracture porosity and permeability, extensive aquifer with intergranular porosity and permeability and aquifer with fracture porosity and permeability.

\section{Aquifer with Intergranular Weathered and Fracture Porosity and Permeability (High productivity)}

Unconsolidated sediments and the underlying volcanic rocks constitute such aquifers that are characterized by the presence of both intergranular and fracture porosity and permeability (Figure 10). Aquifers of this type are found in northern, northeastern, eastern and central parts of the sub basin (Figure 12). The aquifers are mainly unconfined and confined types.
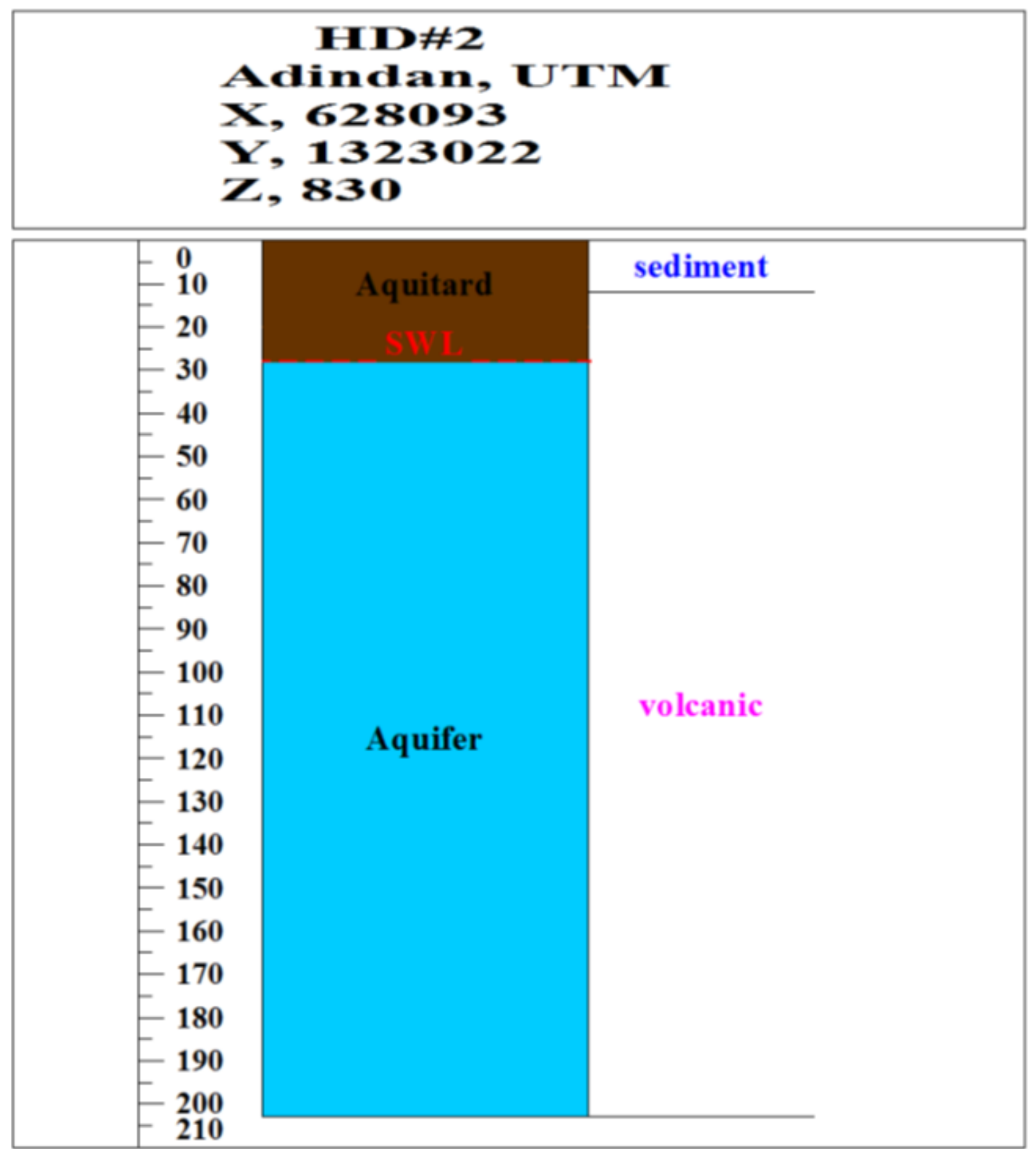

Figure-10. Hydrogeological log of HD2 irrigation well with high productivity of Quaternary basaltic aquifer. Source: Gobeze Begashaw, M.Sc. Thesis, University of Mekelle, Mekelle, Ethiopia, 2016.

Extensive Aquifer with Intergranular Porosity and Permeability (High to Very High Productivity)

This is a porous medium constituted mainly by unconsolidated sediments of different types. It is found in limited area coverage in the western parts whereas in the central, eastern, northern and southern parts it is found covering extensive areas. Geological logs data obtained from deep wells drilled in the different parts of the eastern and central parts of the sub-basin (SW 14, SW 19, SW20, SW21, SW23, SW26, SW32, SW33 and SW 35) revealed that the thickness of the fluvo-lacustrine sediments ranges from $166 \mathrm{~m}$ to $200 \mathrm{~m}$. The discharge of these wells ranges from $28 \mathrm{l} / \mathrm{s}$ to $62 \mathrm{l} / \mathrm{s}$ with an average discharge of $49.51 / \mathrm{s}$. The maximum recorded drawdown with a pumping rate of $38 \mathrm{l} / \mathrm{s}$ for $24 \mathrm{hrs}$ is $63.35 \mathrm{~m}$. The sediments are found underlined by volcanic rocks of different types. Moreover this area has also sediments interbedded with volcanic rocks of different types (Figure 11).

\section{Aquifer with Fracture Porosity and Permeability}

This is a fracture medium constituted mainly by fractured volcanic rocks of different types. It is found mainly in the western parts of the sub basin (Figure 12) that are characterized by rugged topography. Since the area is water contributing area to the central and eastern low land areas of the sub basin, the aquifers are low yield aquifers. 


\subsubsection{Aquifer Productivity}

The basic aquifer properties that were considered for evaluating the aquifer potentiality are transmissivity $(\mathrm{T})$, hydraulic conductivity $(\mathrm{K})$ and specific capacity. The pumping test data of 35 deep wells were analyzed and the results are summarized and given in Table 1.

The computed values of hydraulic conductivity ranges from $0.268-31.1 \mathrm{~m} /$ day with mean value of 9.55 $\mathrm{m} /$ day. The lowest one found in the western parts of the study area whereas the highest is found in the eastern parts. The average hydraulic conductivity of the aquifers of unconsolidated sediments by taking 8 irrigation wells is $8.2 \mathrm{~m} /$ day. The result of the analysis also reveal that transmissivity ranges from 9.6 to $2420 \mathrm{~m}^{2} /$ day and specific capacity ranges from 0.07 to $65.31 \mathrm{l} / \mathrm{sec} / \mathrm{m}$ with mean values of $632.79 \mathrm{~m}^{2} /$ day and $5.45 \mathrm{l} / \mathrm{sec} / \mathrm{m}$, respectively.
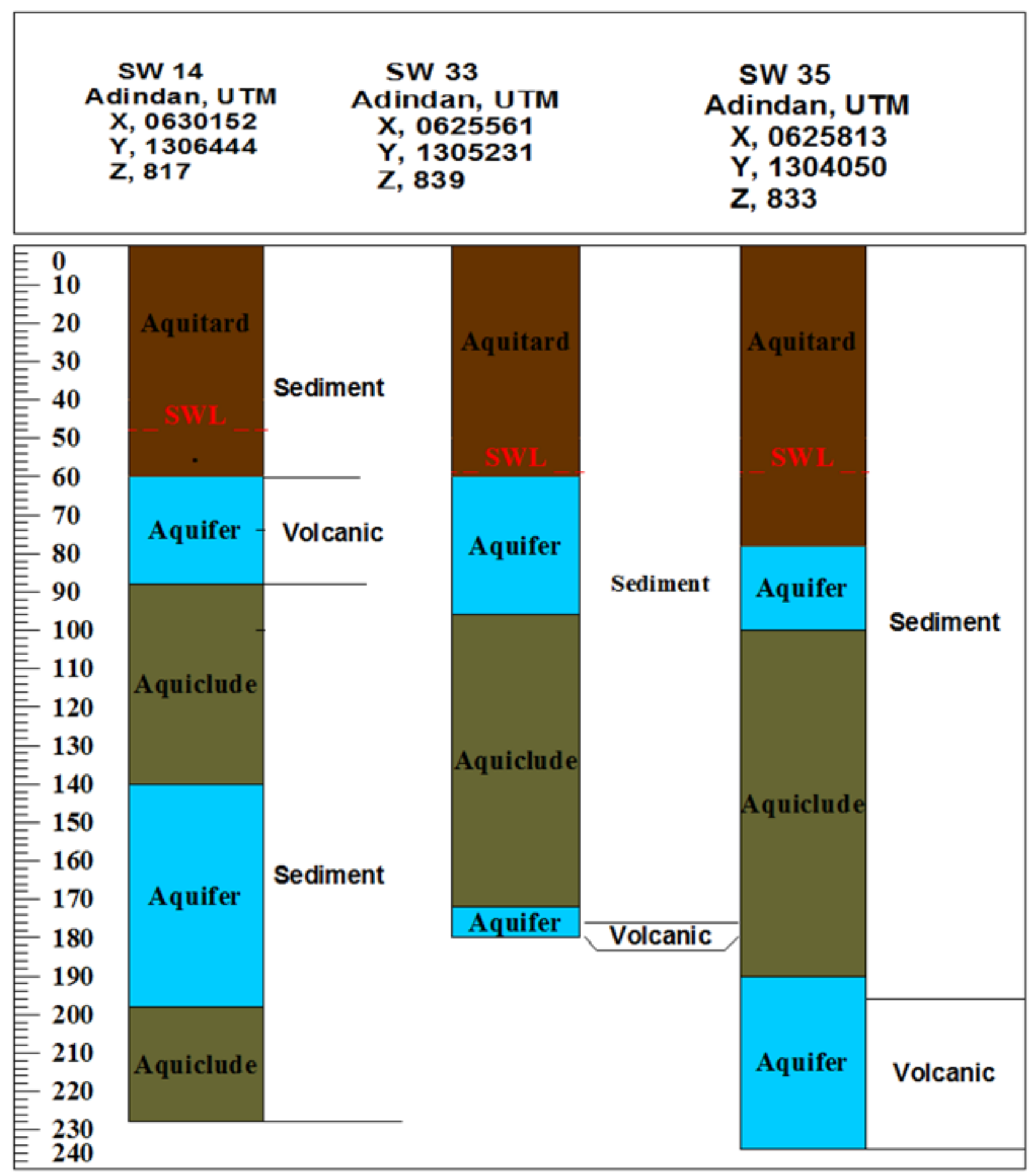

Figure-11. Hydrogeological log of SW 14, SW33 and SW35 drilled in sediments interbedded with volcanic rocks. Source: Gobeze Begashaw, M.Sc. Thesis, University of Mekelle, Mekelle, Ethiopia, 2016. 
Table-1.Computed hydraulic properties of aquifers.

\begin{tabular}{|c|c|c|c|c|c|c|c|c|c|}
\hline No. & Well D & $\mathbf{X}$ & $\mathbf{Y}$ & Depth (m) & $Q(1 / s)$ & $\mathbf{S}$ & Q/Sw & $\mathbf{T}$ & $\mathbf{K}$ \\
\hline 1 & GBH-2 & 563729 & 1301682 & 151 & 2.1 & 32.07 & 0.07 & 9.6 & 0.268 \\
\hline 2 & SWTW 1 & 566480 & 1299859 & 240 & 19.53 & 70.97 & 0.28 & 96.7 & 1.4 \\
\hline 3 & Badule\#2 & 607012 & 1310055 & 286.5 & 28 & 12.57 & 2.23 & 507 & 7.78 \\
\hline 4 & Merto & 627929 & 1308203 & 179 & 22.5 & 7.39 & 3.04 & 245 & 3.41 \\
\hline 5 & Sunuta\#2 & 630875 & 1305530 & 225 & 53 & 10.16 & 5.22 & 1010 & 14 \\
\hline 6 & Sunuta\#6 & 629928 & 1304713 & 216 & 55 & 6.18 & 8.90 & 1220 & 20.1 \\
\hline 7 & $\mathrm{HD} 2$ & 628093 & 1323022 & 203 & 80 & 14.93 & 5.36 & 506 & 12.6 \\
\hline 8 & SW 07 & 629196 & 1305200 & 204 & 64 & 0.98 & 65.31 & 517 & 7.8 \\
\hline 9 & SW 10 & 628394 & 1306098 & 202 & 60 & 3.5 & 17.14 & 2420 & 31.1 \\
\hline 10 & SW 12 & 629484 & 1305759 & 202 & 75 & 25.32 & 2.96 & 644 & 17 \\
\hline 11 & SW 13 & 628801 & 1306978 & 193 & 62 & 4.3 & 14.42 & 1970 & 26.6 \\
\hline 12 & SW 14 & 630033 & 1306230 & 228 & 80 & 12.93 & 5.41 & 519 & 7.21 \\
\hline 13 & SW 15 & 629348 & 1307106 & 200 & 53 & 38.63 & 1.37 & 56.4 & 1.34 \\
\hline 14 & SW 16 & 629209 & 1307721 & 168 & 55.5 & 57.34 & 0.97 & 934 & 19.4 \\
\hline 15 & SW 17 & 628670 & 1307551 & 138 & 53 & 40.98 & 1.29 & 336 & 5.09 \\
\hline 16 & SW 19 & 629083 & 1308282 & 218 & 55.5 & 59.86 & 0.93 & 341 & 4.74 \\
\hline 17 & SW 20 & 628952 & 1308892 & 200 & 50 & 63.35 & 0.79 & 38.6 & 0.68 \\
\hline 18 & SW 21 & 628276 & 1309272 & 176 & 55.5 & 25.5 & 2.18 & 224 & 3.74 \\
\hline 19 & SW22 & 628391 & 1308445 & 124 & 55 & 64 & 0.86 & 513 & 12.2 \\
\hline 20 & SW 23 & 628542 & 1308130 & 212 & 53 & 74.9 & 0.71 & 222 & 2.64 \\
\hline 21 & SW 24 & 629668 & 1308794 & 200 & 52 & 73.57 & 0.71 & 151 & 2.29 \\
\hline 22 & SW 25 & 628808 & 1309507 & 203 & 58 & - & - & 241 & 4.01 \\
\hline 23 & SW26 & 628590 & 1309855 & 214 & 62 & 14.39 & 4.31 & 771 & 8.56 \\
\hline 24 & SW27 & 628471 & 1310444 & 202 & 73 & 8 & 9.13 & 1520 & 21 \\
\hline 25 & SW 32 & 625457 & 1305814 & 174 & 48 & 14.34 & 3.35 & 931 & 12.9 \\
\hline 26 & SW33 & 625468 & 1305024 & 180 & 28 & 6.14 & 4.56 & 906 & 18.9 \\
\hline 27 & SW 35 & 625813 & 1304050 & 235 & 56 & 12.21 & 4.59 & 744 & 10.7 \\
\hline 28 & SW 41 & 625022 & 1307597 & 238 & 50 & 23.89 & 2.09 & 538 & 6.4 \\
\hline 29 & SW 43 & 625793 & 1310860 & 216 & 50 & 27.05 & 1.85 & 980 & 16.3 \\
\hline 30 & SW 44 & 625744 & 1311458 & 240 & 46 & 48.24 & 0.95 & 323 & 3.59 \\
\hline 31 & SW 45 & 625646 & 1312069 & 246 & 46 & 40.37 & 1.14 & 249 & 2.76 \\
\hline 32 & SW 46 & 625615 & 1312667 & 248 & 24 & 40.94 & 0.59 & 300 & 3.34 \\
\hline 33 & SW 49 & 621674 & 1309303 & 246 & 30 & 68.35 & 0.44 & 131 & 1.46 \\
\hline 34 & SW 50 & 621759 & 1308681 & 246 & 50.6 & 4.49 & 11.27 & 1943 & 21.6 \\
\hline 35 & SW 53 & 622123 & 1307034 & 240 & 40 & 48.72 & 0.82 & 90.3 & 1.25 \\
\hline
\end{tabular}

In this research, based on the analyzed result of transmissivity and specific capacity, an attempt was made to classify the aquifers of the study area into different class of potentiality. This classification was made on the basis of Sen [8] scheme.

Accordingly, the unconsolidated sediments and volcanic rocks of the study area are grouped into three-aquifer group. These are:

1. Low potential aquifer (Tertiary volcanics and overlaying sediment);

2. Moderate potential aquifer (Alluvial and fluvo-lacustrine sediments with underlying volcanic rocks); and,

3. Highly potential aquifers (Fluvo-lacustrine sediments and underlying basalts and rhyolites).

\section{Low Potential Aquifer}

Low potential aquifer is mainly found in the western part of the study area (Figure 12). As it was observed during field survey, Tertiary Ashange basalt fractures are filled by secondary minerals such as calcite and zeolites which decrease the permeability and porosity. The overlying alluvium is also dominated by silt and clay. The computed hydraulic conductivity and transmissivity for the borehole drilled in this aquifer is $0.27 \mathrm{~m} /$ day and $11.7 \mathrm{~m}^{2} /$ day. A continuous pumping test was conducted for 1440 minute with a discharge of $2.11 / \mathrm{s}$ and the maximum drawdown recorded was $32.07 \mathrm{~m}$. The SWL is $44.66 \mathrm{~m}$ and the depth of the borehole is $151 \mathrm{~m}$.

\section{Moderate Potential Aquifer (Alluvial and Fluvo- Lacustrine Sediments with Underlying Volcanic Rocks)}

This aquifer is located in the western parts adjacent to the rivers and also in the eastern parts occupying topographically low land areas (Figure 12). Transmissivity values computed from pumping test data of the deep wells that were drilled in this aquifer in the eastern parts of the sub-basin ranges from $50-500 \mathrm{~m}^{2} /$ day, indicating the moderate potential aquifer. In the western parts computed transmissivity and hydraulic conductivity (Table 1) from pumping test data of the deep wells that is drilled in this aquifer also reveal moderate potentiality nature of this aquifer.

\section{High Potential Aquifers (Fluvo-Lacustrine Sediments and Underlying Basalts and Rhyolites)}

This aquifer types is found in the eastern and northeastern parts of the sub-basin (mainly in the Afar depression, Figure 12) forming multilayer aquifer system. Deep wells that have a depth ranging from 124 to $286.5 \mathrm{~m}$ were found drilled in this area for domestic and irrigation purposes. The discharges of the wells range from 221/s (for water supply wells) to 80l/s for (irrigation wells). The lithological logs of these wells show that the thickness of the sediment ranges from 166 to $200 \mathrm{~m}$ with the interlayered weathered-fractured basalt and rhyolite. Transmissivity values these multilayer aquifers computed from pumping test data of the deep wells ranging from 500 to $2420 \mathrm{~m}^{2} /$ day. 


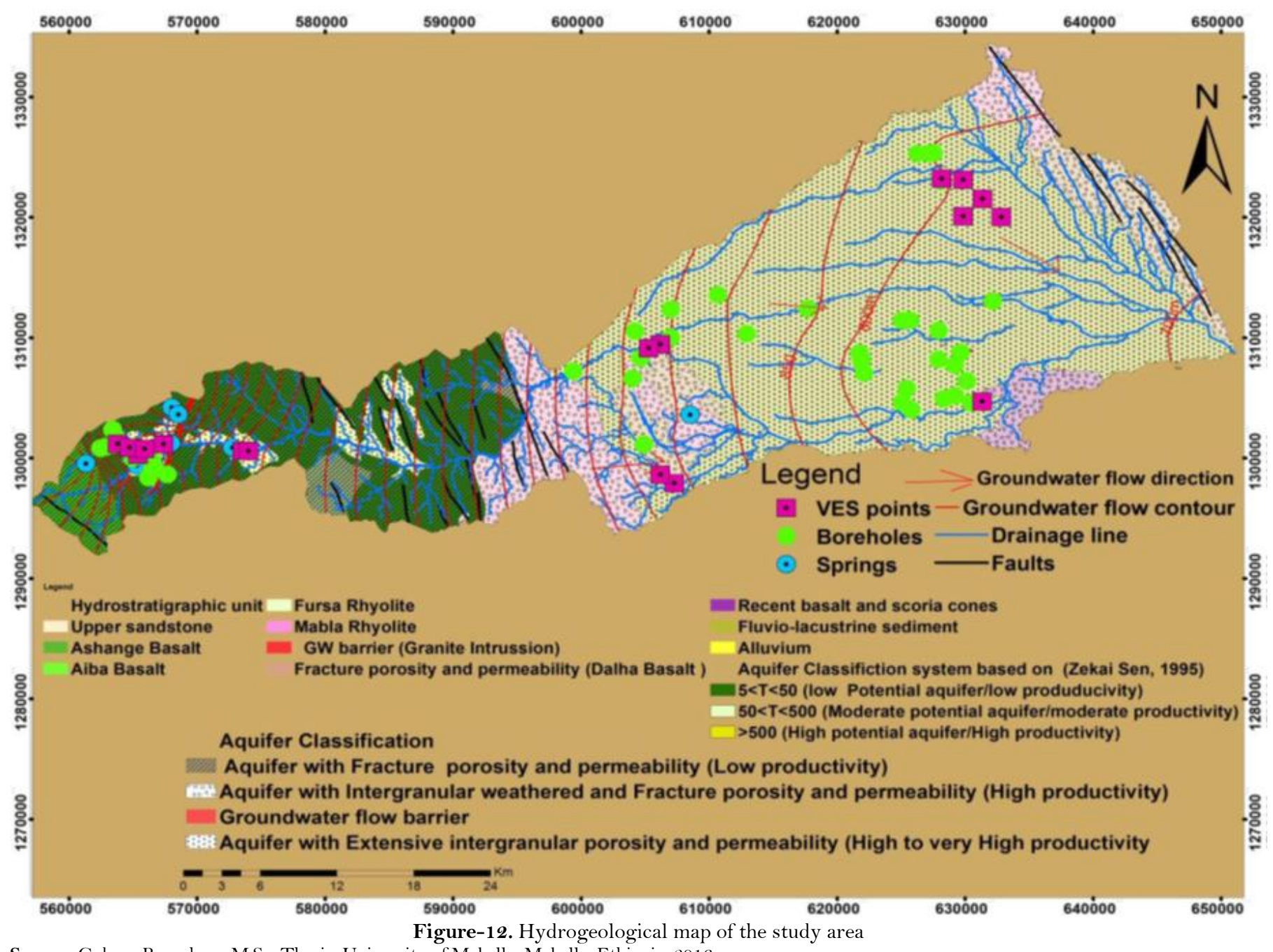

Source: Gobeze Begashaw, M.Sc. Thesis, University of Mekelle, Mekelle, Ethiopia, 2016.

\section{Conclusions}

The different geological formations that are found constituting the area are categorized hydrogeologically into aquifer with intergranular weathered and fracture porosity and permeability, extensive aquifer with intergranular porosity and permeability and aquifer with fracture porosity and permeability.Confined, unconfined, and semiconfined aquifer types, which exist as multilayer aquifer system, are the major aquifer types that were identified in the area.

Analysis of pumping test data revealed that hydraulic conductivity ranges from 0.268 to $31.1 \mathrm{~m} /$ day and transmissivity ranges from 9.6 to $2420 \mathrm{~m}^{2}$ /day with mean values of $9.55 \mathrm{~m} /$ day and $632.79 \mathrm{~m}^{2} /$ day, respectively. This variation of both hydraulic conductivity and transmissivity is a result of differences in intensity of weathering, degree of fracturing and interconnectivity nature of fractures in the volcanic rock units. Specific capacity ranges from 0.07 to $65.31 \mathrm{l} / \mathrm{sec} / \mathrm{m}$ with mean values of $5.45 \mathrm{l} / \mathrm{sec} / \mathrm{m}$.

On the basis of their corresponding transmissivity and specific capacity value, the different aquifers of the studied area were categorized into three aquifer potentiality groups: low, moderate and high potentiality aquifer. Any future development of groundwater should be focused on the moderate and high potentiality aquifers.

\section{References}

[1] P. H. Gleick, "Water resources" in Encyclopedia of Climate and Weather, ed. by. S. H. Schneider vol. 2. New York: Oxford University Press, 1996.

[2] K. M. Hiscock, Hydrogeology principles and practice. United Kingdom: School of Environmental Sciences University of East Anglia, 2005 .

[3] G. P. Kruseman, Analysis and evaluation of pumping test data, 2nd ed. Wageningen, The Netherlands: International Institute for Land Reclamation and Improvement, 1990.

[4] B. Alebachew and A. G. Mohamed, Tectonics of the Afar depression: A review and synthesis. Richardson, TX 75083-0688, USA: Department of Geosciences, The University of Texas at Dallas, 2005.

[5] J. Varet, Geology of central and Southern Afar (Ethiopia and Djibouti Republic) F. Gasse for chapter IV on Sedimentary Formation, Eds. Paris: CNRS, France, 1978.

[6] G. D. Acton, S. Stein, and J. F. Englen, "Block rotation and continental extension in Afar: A comparison to oceanic microplate systems," Tectonics, vol. 10, pp. 501-526, 1991. View at Google Scholar $\mid$ View at Publisher

[7] Water Works Design and Supervision Enterprise, "Teru area groundwater potential assessment project," Draft Phase I Geology Report, Addis Ababa, 2011.

[8] Z. Sen, Applied hydrogeology for scientists and engineers. London: CRS Press, Lewis Publishers, 1995. 